DOI: $10.22616 /$ REEP.2019.002

\title{
Teachers during Education Reforms: Challenges and Opportunities
}

\author{
Zenta Anspoka ${ }^{1} \mathrm{PhD}$; Dace Kazaka ${ }^{2}$ Mag. paed. \\ University of Latvia, Latvia \\ zenta.anspoka@lu.1v; dace.kazaka@lu.1v²
}

\begin{abstract}
Topicality of the research problem is connected with global and local processes and education policy in the society. In order to solve several topical issues on the quality of education, educational reforms are frequently implemented in different countries, also including Latvia. The aim of the study is to analyse education policy guidelines, theoretical studies and the results of the empirical research on the teachers' activity and needs to begin to implement the education reform on competence-based content development. The research methodology includes analyses of education guidelines, theoretical studies and surveys obtained from 146 teachers from comprehensive schools in Latvia. The teachers are ready to implement education reform, but the low self-initiative confines to execution of regulations, rules or instructions given by the school's leaders. The teachers appreciate highly their professionality, takes responsibility for the work within their subjects, but dissociate themselves from the responsibility for the whole teaching and learning process in the school, does not stand out with autonomy to make decisions independently. The obtained outcomes are the proof to the fact that attention has to be paid teachers' mutual collaboration, as well as development of pedagogy as science.
\end{abstract}

Keywords: education reform, collaboration, professional competence, school education.

\section{Introduction}

The need for education reforms is determined by factors such as during the last decade the amount of information and its pace of circulation increase in the society, new revelations emerge, technologies develop really fast, the need for new knowledge and skills appear. In the society the interest in the quality of education rises and the education system in every country is forced to respond to the society's needs to introduce changes in the study process on all levels and education system in general.

From international perspective education reforms identified by the needs to implement requirements by the OECD (Organization for Economic Cooperation and Development) and PISA (Programme for International Student Assessment), which emphasize the need to review the goal of the education programmes in order to eliminate the contradiction between knowledge and skills, which are necessary in the future world, eliminate fragmentation of the content, strengthen the link between the educational establishment and community, encourage development of every individual's critical thinking, creativity and responsibility. A school as an organization is forced to change and adapt new conditions constantly, and every teacher individually and together with other colleagues learn to acquire new knowledge and skills, interact with each other and study regularly the outcomes of own work, analyse them and search for the ways of problem-solving (21st Century Learning..., 2007; Excellence and Equity..., 2016).

On the one hand, schools and society understand the necessity for different reforms and they support them, but on the other hand, there is also an opposition or, at least, the "procrastination mode," as in a sustainable work group or social memory enables them to remember the reforms of previous stages and the problems related to them. The most worrying issue is whether the ones involved in the reforms will possess a critical mind, perceive and deeply understand the essence of the reform, in its process will not lose the stable values accumulated through several decades, but on the contrary - will apply them purposefully in new conditions (Fadel, Bialik, Trilling, 2015).

As a reform is certain changes, rearrangement in a particular sphere of public life without changing the base of the current social structure, but in order to improve it, then the educational reform is not understood as a "revolution", but rather transformation, rearrangement and improvement of the educational content in compliance with the $21^{\text {st }}$ century's educational goal to help every human learn to live in accordance with nature and other cultures, be able to self-realize and provide long-term and wellconsidered application of natural and public resources, be aware of the local problems and recognize its topicality in the global context, know the traditions of own culture and treat traditions of other cultures 
with respect, as well as take responsibility for the society's sustainability and its growth $\left(21^{\text {st }}\right.$ Century Learning..., 2007; Hargreaves, Fullan, 2012; Fadel, Bialik, Trilling, 2015).

Educational Reforms The school in 2030 (Skola 2030.., 2018) radically reverse the approach to teaching in Latvia, with the emphasis on student performance and their ability to use knowledge and skills acquired in school. Education reform supports the learning of each student and implements learning through an in-depth approach, emphasizing self-directed learning skills, improving the methodology of motivating the students' interest, increasing the students' ability to formulate and ask questions and developing cooperation skills in order to give recommendations to classmates (Pridane, 2018). The reform of the teaching/learning content envisages the implementation of the competence approach. This means that the focus on self-regulated learning, construction of knowledge and its application in diverse situations increases. Possibilities should be ensured for learners in the learning environment to apply their knowledge in diverse situations (Andersone, 2017).

The aim of the study is to analyse education policy guidelines, theoretical studies and the results of the empirical research on the teachers' activity and needs to begin to implement the education reform on competence-based content development.

\section{Methodology}

Research is based on analyses of education policy guidelines and theoretical studies (Excellence and Equity..., 2016; Citizenship Education at..., 2017; Skola 2030.., 2018; Fadel, Bialik, Trilling, 2015; Fullan, 2015; Hargreaves, Fullan, 2012; Kidron, Kali, 2015; Danielson, 2007; Macisanas lietpratibai..., 2018). The question of the study is how comprehensive school teachers understand the purpose of the education reform on competence-based content development and what kind of assistance is needed.

Empirical research is based on survey results from 146 comprehensive school teachers in Latvia. The study carries out a quantitative and qualitative content analysis. The obtained data have been analysed, using individual parts (how many times one and the same name has been repeated in the replies related to the research problem), as well as analysis of the replies' meaning (the responses were structured in logical units and interpreted from the scientific point of view. The quantitative data are expressed in figures and is analysed in the text.

\section{Results and Discussion}

Nowadays there is nothing more unique than the human being. In the $21^{\text {st }}$ century it is also essential to acquire the universal and individual values, particular knowledge and skill to apply them. The base for everything is still languages, mathematics, natural and social knowledge. Only due to the increase of the information amount and variety of resources, more attention should be paid to the knowledge, what the knowledge acquisition ways of the previously mentioned areas are, what one has to know, how to access information and how to work with it. The issue how we do it, with what means becomes topical, and this already becomes the teacher's responsibility, for we do train our students for the workplaces which do not exist yet, for information technologies which will only be made and we teach them to solve the problems, about which we have not got a clue yet (Macisanas lietpratibai..., 2018; Fadel, Bialik, Trilling, 2015).

Justification of the education reform can be found in the fact that in practice there is a certain gap between the knowledge and skills students acquire at school and what is required by the society.

Teachers realize the standards of the comprehensive school subjects in order the student could pass successfully the centralized examinations. It creates the situation that the student only acquires a limited experience. The student, who can do more and better than what has been envisaged in the standards as the result to be achieved, are being discriminated to a certain extent (Anspoka, Kazaka, 2017).

The teachers need a new way of thinking about teaching and learning process in the school and school as an organisation in local society (Excellence and Equity..., 2016).

Traditionally, teachers have primarily taught school subjects. Today, however, we are moving away from subjects and towards a future where teachers will increasingly teach comprehensive learning skills. New technologies will also be integrated into teaching, and learning environments will be increasingly modified to promote learning (21 st Century Learning..., 2007; Skola 2030..., 2018; Hattie, 2009). 
Nowadays important school's task is to eliminate fragmentation and duplication in different subjects, provide succession of learning content acquisition and an opportunity for each pupil to see interconnections between the acquired in different areas, apply their knowledge in practice. If we want to improve education outcomes, we need to develop understanding of interdisciplinary teaching/learning of the learning content (Kidron, Kali, 2015).

No less important issue is to pay attention to a more profound awareness of the integrity of the internal and external structure of the learning process. Components of the learning process - goal of learning, learning content and methodology for its implementation are as important as how the student's activity for the information perception, comprehension and application is induced, such a cognitive action path in which topicalization of the previous experience happens, its comparison with what new has been revealed, analysis and synthesis of the previously acquired and newly acquired experience. Being aware of students varied experience, the professional teacher has to be able to direct the teaching and learning process from the monologue to the dialogue, from the convergent thinking, in which there is only one right opinion, to the divergent thinking, in which the teacher's opinion is also one of the opinions. We cannot afford to neglect the talented, with special abilities gifted pupils (Anspoka, 2016).

Without denying the role of technologies in the learning process, in practice they are perceived rather than as an additional tool and not as one of the learning process resources, which enable them to acquire new knowledge and skills, broaden their intellectual and emotional experience.

Nowadays students have the necessity to acquire skills to deal with information, applying various resources which are not just textbooks. Without denying that nowadays there are two worlds - the real and virtual world, it is important to help the student acquire the skill to work with different information and to distinguish real information from false information.

One of the teacher's challenges nowadays is to help the student understand the cultural environment, relationships with people of different cultures and life experience, and for it, such personalities as empathy, resilience, ability to take initiative, assess the situation quickly and make independent decisions are necessary (Excellence and Equity..., 2016; Skola 2030..., 2018; Danielson, 2007).

Today a high level of self-initiative and entrepreneurship skills are important for the teacher, in order to be able to transform any idea, as long as it is a purposeful one, into action. It requires from the teacher not only creativity, but also the skill to set goals and means for its implementation. The courage to take risks, ask for help, if it is necessary, get rid of dogmas, doubts, which slow down development, are not less important (Hargreaves, Fullan, 2012; Fadel, Bialik, Trilling, 2015).

One of the teacher's challenges during the education reform is to find balance between the traditional and innovative, understand that the teacher's experience integrated with the student's experience gives a wider experience, also teachers to share responsibility for the work outcomes between both cooperation partners. The modern global dynamism, frequent new challenges require to acquire the skill to plan one's work, moreover, not in a too far long-term, but for the time period in which one can see the result, see the success, what has to be changed and how it can be done the best (Fullan, 2015; Hargreaves, Fullan, 2012).

The challenge is topical to understand what the student's and teacher's responsibility during the teaching and learning process is, how broad the teacher's knowledge is on how to shape such a learning process in which the teacher's responsibility is not to pass on the knowledge, but teach students to obtain knowledge and know how to use it (Macisanas lietpratibai..., 2018).

The teacher also has to be theoretically prepared to see the process of changes from all aspects more broadly and profoundly, in order not to waste time and energy. Only personal and professional courage and responsibility do not allow to lose balance (Danielson, 2007).

One of the education reform's justification is based on the fact that the teacher has to be prepared to apply the obtained experience in the teaching and learning process, for it is also important for the student to recognize themselves and know how they learn themselves, how to perceive and memorize the information more easily. It facilitates the control of the learning process. It is a really important aspect, for one of the most significant learning stages is to acquire the skill to be independent - a personality who takes responsibility for their learning. It has to be part of the learning process, which enables the individual to acquire constantly the changeable knowledge also without any help from others. If the 
student is aware and knows how it is better for them to learn, the confidence in the ability to learn independently increases, the need for the control from the teacher's side decreases and the statement whether the result complies with a certain sample, regulations is less expected. The teacher's work today is to lead the student, who has taken own responsibility for their learning (Hattie, 2009; Fadel, Bialik, Trilling, 2015; Macisanas lietpratibai..., 2018).

Since a wide-ranging education reform on competence-based content development and implementation on all levels of education (Macisanas lietpratibai..., 2018) has been going on also in the education system of Latvia for the last two years, then in the reform involved people's awareness of the reform's purpose, as well as the ability to see what kind of help is necessary is a topical issue.

Education reform on competence-based content development aim is to develop content of education and the approach to teaching, which help to students acquiring the knowledge, skills and attitudes for life in the 21 st century. Deep learning is a general approach as a way during which pupils develop their ability to generalise or transfer their new knowledge and skills to new and unknown situations (Skola 2030.., 2018).

Surveying teachers of comprehensive schools, $92 \%$ of the mentioned respondents admit the need for the education reform, and the most important reason, stating the need for the reform, is in the practice existing, on the one hand, the useless overlapping of the learning content in different subjects, on the other hand, the contrary situation - the teachers' reliance on each other, and due to it, nowadays students do not acquire the essential particular knowledge and skills in any of the subjects.

These teachers from comprehensive schools are professionally ready for rearrangements both in the teaching and learning content and methodology for its implementation and look to school as a place to implement conscious research activity which would allow to cognize how rearrangements happen and what help is necessary, how to develop events for further improvement. The respondents mentioned above are convinced that during the education reform the teacher can receive the necessary support first of all in the corresponding school. School as an organization with its culture and systemic activity can provide the teacher further education activities, mutual learning opportunities and teamwork, activate teachers to make common or at least coordinated study programmes, teaching and learning aids, develop an exchange system of information and experience, stimulate and support the growth of the teachers. In addition, mutual trust, regular discussion about the professional work research data, application of the obtained experience for further work planning, acknowledgement and public assessment of the common and individual achievements, active involvement on the national level and other events are not less important.

Nevertheless, $8 \%$ teachers of comprehensive school are confident that no rearrangements are needed, as they consider that in their institution everything happens according to the age requirements, and every reform just "knocks" the people out of the daily work rhythm, its comfort zone, which has been created during a longer period of time.

Attention should be paid to the data which confirm that $67 \%$ teachers of comprehensive school are waiting from education reform the greatest benefit to improve the different subject teachers and mutual cooperation, development of a coherent study programme and teaching and learning materials, the teachers' theoretical knowledge and practical work experience.

The survey findings suggest $93 \%$ of the respondents are critical of their professional competence and are considering that the most characteristic challenge in the in the teaching and learning process is less speaking, but more managing the process. Questions are rightly raised how to do it, how to decrease the number of tasks which require explanations, talking, how to encourage the individual work.

The research outcomes enable us to think that one of the problems for more successful work, when implementing the set requirements for modern teaching and learning process, is insufficient communication among the different subject teachers. Four percent of teachers admit that teachers perceive their colleagues not as cooperation partners but rather than competitors. According education reform's purpose to improve education outcomes, $82 \%$ of the surveyed respondents admit that not only the subject teachers' mutual collaboration, but also the teachers and support staff's (librarians, psychologists, social pedagogues, speech therapists, career consultants) cooperation has to be improved. According to the respondents, in general the cooperation exists, but it is episodic, mostly, in a special situation. In order to promote a more purposeful teaching and learning process, respondents acknowledge the need for regularity and collaboration in the particular system. 
According to the data, $26 \%$ of teachers have low self-initiative, they mostly want to execute the normative acts, educational politicians or school leaders' regulations well, justifying it with the fact that they do not feel safe or they do not understand the goal, content and other issues of the education reform well enough, also they do not want to take extra responsibility, they are afraid of making mistakes, receiving allegations from the administration and colleagues. Among these respondents there are the ones who think they will wait what the decisions are made during the education reform and then they will implement them. Seventy-four percent of the respondents think of themselves as active members of the reform, for they are confident of their competency in the education field and know how to affect the quality of education. It means we are forced to take into consideration some of teachers need the external help, and it should be respected. The teachers need help on how to assess critically more successfully their professional competence and notice what has to be changed, how to accomplish it, if necessary, who ask help for, how to overcome stress and critical situations.

As a contribution to the professional competence development, $88 \%$ surveyed teachers acknowledge the provided opportunities to get to know the experience of other countries, different teaching and learning theories, the already approbated practice in other countries, but it is connected with another problem. However, alongside that both teachers-practitioners and scientists have got more responsibility in the development of the pedagogical terminology.

As research shows, carrying out improvements in the education process and adapting the experience of other countries, the problem of translation emerges. Respondents admit that the situation appears due to insufficient profound theoretical knowledge and it causes insecurity, and teachers, even leaders of schools accept the terms used in a foreign language without any critical assessment, transfer them literally to their language and get lost in translation.

Implementing education reform on competence-based content development introducing a new approach and new methods in education, one cannot deny completely the current experience; a new term in a foreign language is not always related to a new term. Adoption of foreign words without any justification should be avoided. If the meaning of a word is understood precisely, it can also be expressed successfully in the mother tongue. It is a distributed responsibility to preserve and maintain also the national aspect of pedagogy.

\section{Conclusions}

Education reform as the process of education content transformation, rearrangement and improvement in compliance with the $21^{\text {st }}$ century's education goal is necessary in order to maintain the quality of education and eliminate such problems based on the education guidelines and theoretical studies as overlapping of the learning content or insufficient acquisition of knowledge and skills topical nowadays, whose cause most often is the insufficient teachers collaboration,students' inability to lead and assess the cognitive activity themselves, taking responsibility for the result.

Teachers from comprehensive schools are professionally ready for education reform on competence-based content development and implementation on Latvia, they acknowledge the need for them and during the education reform the teacher can receive the necessary support first of all in the corresponding school.

School as an organization with its culture and systemic activity can provide the teacher's further education activities, mutual learning opportunities, activate teachers to make common or at least coordinated study programmes, teaching and learning aids, develop an exchange system of information and experience, stimulate and support the growth of the teachers.

The greatest benefit of education reform on competence-based content development and implementation on Latvia is to improve the different subject teachers and mutual cooperation, development of a coherent study programme and teaching and learning aids, the teachers' theoretical knowledge and practical work experience.

One of the tasks is help to teachers with low self-initiative, that they do not feel safe or they do not understand the goal, content and other issues of the education reform well enough, also if they do not want to take extra responsibility, are afraid of making mistakes, receiving allegations from the administration and colleagues.

As a contribution to the professional competence development, teachers acknowledge the provided opportunities to get to know the experience of other countries, different teaching and learning theories, the already approbated practice in other countries. 
Education reform on competence-based content development has also got its place in the development of pedagogy science, and it has to be done, assessing critically the current experience, implementing the new terminology thoughtfully, since a new term in a foreign language is not always related to a new term. Acquisition of a foreign word should be avoided. If the meaning of a word is understood correctly, it can also be expressed successfully in the mother tongue. Scientists and practitioners' distributed responsibility is to maintain and preserve pedagogy as a national science, too.

\section{Bibliography}

1. 21st Century Learning: Research, Innovation and Policy Directions from Resent OECD Policies. (2007). OECD: CERI. Retrieved from http://www.oecd.org/site/educeri21 st/40554299.pdf

2. Andersone R. (2017). The Learning Environment in Today's School in the Context of Content Reform of Curriculum. In V. Dislere (Ed.), The Proceedings of the International Scientific Conference Rural Environment. Education. Personality (REEP), 10. Jelgava: LLU TF, 17-22. Retrieved from http://llufb.llu.lv/conference/REEP/2017/Latvia-Univ-Agricult-REEP2017_proceedings-17-22.pdf

3. Anspoka Z. (2016). Language Diversity in the Classroom and Different Subject Teachers' Professional Competence: Some Problems and Solutions. In R. Golz (Ed.), International Dialogues on Education: Past and Present. IDE-Online Journal, 30- 36. Retrieved from http://www.idejournal.org/article/2016-volume-3-number-3-language-diversity-in-the-classroom-and-differentsubject-teachers-professional-competence-some-problems-and-solutions/

4. Anspoka Z., Kazaka D. (2017). Learning Theories in Modern Scholar Learning Aspect: Different Problems and Solution in Practice. In V. Dislere (Ed.), The Proceedings of the International Scientific Conference Rural Environment. Education. Personality (REEP), 10. Jelgava: LLU TF, 23-29. Retrieved from http://llufb.llu.lv/conference/REEP/2017/Latvia-Univ-Agricult-REEP2017_proceedings-23-29.pdf

5. Citizenship Education at School in Europe. (2017). Retrieved from https://eacea.ec.europa.eu/national-policies/eurydice/content/citizenship-education-schooleurope-\%E2\%80\%93-2017_en

6. Danielson C. (2007). Enhancing Professional Practice: A Framework for Teaching (2 ${ }^{\text {nd }}$ ed.). USA: ASCD publications.

7. Excellence and Equity in Education. PISA 2015 Results (Volume I). (2016). OECD._Retrieved from https://www.oecd-ilibrary.org/docserver/9789264266490en.pdf?expires=1551560060\&id=id\&accname=guest\&checksum=09DC2C0C4EFA3A3E3F681FACE05DA527

8. Fadel C., Bialik M., Trilling B., (2015). Four-Dimensional Education: The Competencies Learners. Needed to Succeed. Boston: The Center for Curriculum Redesign.

9. Fullan M. (2015). The new meaning of educational change ( $5^{\text {th }}$ ed.). Columbia University, NY: Teachers College Press.

10. Hargreaves A., Fullan M. (2012). Professional capital: Transforming teaching in every school. Columbia University, NY: Teachers College Press.

11. Hattie J.A. (2009). Visible learning. A synthesis of over 800 meta-analyses relating to achievement. London: Routledge.

12. Kidron A., Kali Y. (2015). Boundary breaking for interdisciplinary learning. Research in Learning Technology, 23(26496). Retrieved from https://journal.alt.ac.uk/index.php/rlt/article/download/1646/pdf_22

13. Macisanas lietpratibai. Kolektiva monografija (Learning for Competence. Collective Monograph). (2018). Riga: Latvijas Universitate: Akademiskais apgads. Retrieved from https://www.siic.lu.lv/fileadmin/user_upload/lu_portal/projekti/siic/Kolektiva_monografija/Macisana s_Lietpratibai.pdf (in Latvian)

14. Pridane A. (2018). Development of Learning and Feedback Giving Skills in Home Economics and Technologies Education. In V. Dislere (Ed.), The Proceedings of the International Scientific Conference Rural Environment. Education. Personality (REEP), 11. Jelgava: LLU TF, 321-327. Retrieved from http://llufb.1lu.1v/conference/REEP/2018/Latvia_REEP_2018_proceedings_ISSN2255808X.pdf

15. Skola 2030: atbalsts macibu pieejas mainai (School 2030: Support for changing the learning approach). (2018). Retrieved from https://www.skola2030.lv/par-projektu (in Latvian) 